\title{
Pertanggungjawaban Pejabat Pemerintahan Dalam Penggunaan Diskresi Yang Membebani Keuangan Negara
}

\author{
Henny Juliani \\ Fakultas Hukum, Universitas Diponegoro \\ hennyjuliani.fhundip@gmail.com
}

\begin{abstract}
In the concept of welfare state, government has an authority to do discretion in running their tasks to provide public advantage, Discretion basically is prior to effectiveness of objectives than reffering to formal regulations but should be accountable. This research used empirical juridic approach adn the result was analyzed qualitatively, the result showed that Ahok's discretion in the case of Sumber Waras Hospital and Reclamation of Jakarta Gulf did not cause on legal consequency that burdening public finance. Discretion done by Ahok in both cases were accounted for based on norm of administrative law, which stated in Act Number 30 of 2014 regarding Government Administration.
\end{abstract}

Keyword: Government Officer, Discretion, Public Finance

\begin{abstract}
Abstrak
Dalam konsep negara kesejahteraan (welfare state) pemerintah diberikan kebebasan bertindak (diskresi) dalam penyelenggaraan pemerintahan demi kepentingan rakyat. Diskresi pada asasnya lebih mengutamakan keefektifan suatu tujuan daripada berpegang pada ketentuan hukum namun tetap harus dapat dipertanggungjawabkan. Penelitian ini menggunakan pendekatan yuridis empiris dan hasilnya dianalisis secara kualitatif. Hasil penelitian menampakkan bahwa diskresi Ahok dalam kasus Rumah Sakit Sumber Waras dan Reklamasi Teluk Jakarta tidak menimbulkan akibat hukum yang berpotensi membebani keuangan negara. Diskresi yang dilakukan Ahok dalam kedua kasus tersebut dapat dipertanggungjawabkan berdasarkan kaidah-kaidah Hukum Administrasi Negara yang secara normatif diatur dalam Undang-Undang Nomor 30 Tahun 2014 tentang Administrasi Pemerintahan.
\end{abstract}

Kata Kunci: Pejabat Pemerintahan, Diskresi, Keuangan Negara

\section{A. Pendahuluan}

Pasal 4 ayat (1) Undang-Undang Dasar Negara Republik Indonesia Tahun 1945 menegaskan bahwa Presiden Republik Indonesia memegang kekuasaan pemerintahan menurut Undang-undang Dasar. Kekuasaan pemerintahan yang 
dimiliki oleh Presiden Republik Indonesia tersebut dimaksudkan untuk mencapai tujuan negara dalam menyejahterakan rakyat sebagaimana diamanatkan dalam Pembukaan Undang-undang Dasar Negara Republik Indonesia Tahun 1945. Ketentuan tersebut dirinci lebih lanjut dalam Pasal 33 dan 34 yang menjadi dasar pelaksanaan tugas konstitusional negara/pemerintah yang didukung oleh seluruh komponen bangsa.

Tugas negara/pemerintah dalam mewujudkan kesejahteraan rakyatnya tersebut tidak bisa terlepas dari perkembangan kenegaraan dan pemerintahan setelah Perang Dunia II bahwa konsep negara hukum yang baru adalah negara kesejahteraan (welfare state). Konsep negara kesejahteraan ini menempatkan pemerintah untuk berperan aktif dalam kehidupan sosial ekonomi masyarakat dalam mewujudkan kesejahteraan umum (bestuurszorg), di samping tetap berperan dalam menjaga keamanan dan ketertiban. Oleh karena itu maka peran pemerintah makin lama makin luas.

E. Utrecht sebagaimana dikutip oleh Ridwan HR, menyatakan bahwa diberinya tugas "bestuurszorg" itu membawa bagi administrasi negara suatu konsekuensi yang khusus. Agar dapat menjalankan tugas menyelenggarakan kesejahteraan rakyat, menyelenggarakan pengajaran bagi semua warga negara, dan sebagainya secara baik, maka administrasi negara memerlukan kemerdekaan untuk dapat bertindak atas inisiatif sendiri, terutama dalam penyelesaian soal-soal genting yang timbul dengan sekonyong-konyong dan yang peraturan penyelenggaraannya belum ada, yaitu belum dibuat oleh badan-badan kenegaraan yang diserahi fungsi legislatif. ${ }^{1}$

Pemberian kewenangan kepada administrasi negara untuk bertindak atas inisiatif sendiri itu lazim menurut S.A. de Smith dikenal dengan istilah freies ermessen atau discretionary power, suatu istilah yang di dalamnya mengandung kewajiban dan kekuasaan yang luas. Kewajiban adalah tindakan yang harus dilakukan, sedangkan kekuasaan yang luas itu menyiratkan adanya kebebasan memilih; melakukan atau tidak melakukan tindakan. Dalam praktik antara kewajiban dan kekuasaan berkaitan

Ridwan HR, Hukum Administrasi Negara Edisi Revisi, (Jakarta: Raja Grafindo Persada,2013), halaman 15 
erat. ${ }^{2}$ Nata Saputra mengartikan freies ermessen suatu kebebasan yang diberikan kepada alat administrasi, yaitu kebebasan yang pada asasnya memperkenankan alat administrasi negara mengutamakan keefektifan suatu tujuan daripada berpegang teguh kepada ketentuan hukum. ${ }^{3}$

Freies Ermessen atau diskresi dimiliki oleh setiap pemegang jabatan atau pejabat pemerintahan untuk mengambil kebijakan strategis berupa keputusan atau tindakan dalam mengatasi persoalan konkrit yang mendesak yang membutuhkan penanganan segera. Diskresi yang dilakukan pejabat pemerintahan seringkali menimbulkan polemik di masyarakat, bahkan dapat dianggap berpotensi merugikan keuangan negara. Hal tersebut dapat dilihat antara lain dalam kasus RS Sumber Waras dan Reklamasi Teluk Jakarta. Dalam kedua kasus tersebut dipertanyakan tentang tindakan Basuki Tjahaja Purnama (Ahok), apakah termasuk diskresi atau bukan dan bagaimana akibatnya terhadap keuangan negara/daerah?.

Kebijakan pejabat pemerintahan yang diimplementasikan dalam wujud diskresi seharusnya dilindungi oleh payung hukum, sehingga setiap pejabat pemerintahan yang melakukan tindakan atas nama jabatannya dan digunakan untuk kepentingan publik akan mendapatkan perlindungan hukum. Hukum Administrasi Negara menjadi instrumen perlindungan hukum, sebagaimana diatur dalam Undang-Undang Nomor 30 Tahun 2014 tentang Administrasi Pemerintahan. Undang-undang tersebut memberikan jaminan kepada pejabat pemerintahan bahwa tuntutan untuk mencapai suatu keputusan/tindakan yang adil serta fleksibel dalam penyelenggaraan pemerintahan modern merupakan keniscayaan, sehingga diskresi dipandang akan mampu memberikan sumbangan penting bagi kepentingan umum.

Berdasarkan hal-hal tersebut di atas, maka akan dilakukan penelitian dengan judul: "Pertanggungjawaban Pejabat Pemerintahan dalam Penggunaan Diskresi yang Berpotensi Membebani Keuangan Negara (Studi Kasus Ahok dalam Perkara RS Sumber Waras dan Reklamasi Teluk Jakarta)."

Hal yang ingin diketahui dalam penelitian ini adalah tentang 
pertanggungjawaban pejabat pemerintahan dalam penggunaan diskresi yang berpotensi membebani keuangan negara.

\section{Metoda Penelitian}

Masalah pokok dalam penelitian ini adalah pertanggungjawaban pejabat pemerintahan dalam penggunaan diskresi yang berpotensi membebani keuangan negara. Masalah tersebut dikaji dari sudut pandang hukum dengan menggunakan pendekatan yuridis empiris, karena masalah yang akan diteliti tersebut berhubungan erat dengan law in action. Berbagai temuan di lapangan yang bersifat individual akan dijadikan bahan utama dalam mengungkapkan permasalahan yang diteliti dengan berpegang pada ketentuan yang normatif. Oleh karena itu maka spesifikasi penelitian yang digunakan adalah deskriptif analitis, yang selanjutnya bahan-bahan tersebut akan dianalisis secara kualitatif.

\section{Kerangka Teori}

Berkaitan dengan konsep negara kesejahteraan yang merupakan revisi dari konsep negara pasif, Asshiddiqie sebagaimana dikutip oleh W Riawan Tjandra menguraikan bahwa dalam konsep negara kesejahteraan ini, negara dituntut untuk memperluas tanggung jawabnya kepada masalah-masalah sosial ekonomi yang dihadapi rakyat banyak. Perkembangan inilah yang memberikan legalisasi bagi 'negara intervensionis' abad ke 20. Negara justru perlu dan bahkan harus melakukan intervensi dalam berbagai masalah sosial dan ekonomi untuk menjamin terciptanya kesejahteraan bersama dalam masyarakat. Walhasil dengan intervensi ini fungsi negara juga meliputi kegiatan-kegiatan yang sebelumnya berada di luar jangkauan fungsi negara, seperti memperluas ketentuan pelayanan sosial kepada individu dan keluarga dalam hal-hal khusus seperti 'social security', kesehatan, kesejahteraan sosial, pendidikan, dan pelatihan serta perumahan. ${ }^{4}$

Dalam arti konsep pelayanan publik S.F. Marbun mengemukakan bahwa konsep pelayanan berarti membicarakan tentang cara yang dilakukan untuk

4 W Riawan Tjandra, Hukum Administrasi Negara, (Yogyakarta: Penerbit Universitas Atma Jaya, 2008), halaman 9. 
memberikan servis atau jasa kepada orang yang membutuhkan, sedangkan kata publik berasal dari bahasa Inggris, yakni public berarti masyarakat, umum, rakyat umum, orang banyak dan keperluan umum. Kemudian dalam Bahasa Indonesia, publik berarti orang banyak (umum). Dengan demikian pelayanan publik merupakan kegiatan membantu masyarakat (stakeholders) dalam rangka memperoleh servis dan advis yang terkait dengan kepentingan umum. ${ }^{5}$

Penyelenggaraan pelayanan publik oleh negara merupakan manifestasi konsep negara kesejahteraan (welfare state), karena dalam konsep negara kesejahteraan pemerintah diberikan kewenangan yang luas dalam penyelenggaraan kepentingan umum atau dengan kata lain pemerintah diberikan kewenangan untuk bertindak/berbuat secara aktif mencampuri urusan sosial ekonomi warganya. Dalam konsep ini pemerintah menyelenggarakan kewajiban untuk mewujudkan kesejahteraan rakyat melalui pendidikan, pemberian pelayanan kesehatan, penyediaan dan perluasan lapangan kerja, dan penyelenggaraan tugas-tugas pemerintahan yang lain.

Dalam konsep negara kesejahteraan tersebut, Pemerintah juga diberikan kebebasan bertindak (diskresi) dalam penyelenggaraan pemerintahan untuk menghadapi suatu persoalan konkret agar segera diperoleh penyelesaiannya

\section{Diskresi dalam Penyelenggaraan Pemerintahan}

Krishna Djaya Darumurti menyatakan bahwa pusat isu teoritiskonseptual dalam menganalisis konsep diskresi adalah tegangan (tension) yang terjadi antara tindakan menjalankan undang-undang (atau peraturan perundangundangan dalam pengertian yang lebih luas) secara legalistik versus tindakan menyimpang dari undang-undang (atau peraturan perundang-undangan dalam pengertian yang lebih luas). ${ }^{6}$ Secara logika, tindakan yang disebut lebih akhir menimbulkan perdebatan tanpa dapat diberikan justifikasi yang memadai. Misal, tindakan tersebut dapat dikualifikasikan secara sumir sebagai pelanggaran hukum; penyalahgunaan kekuasaan karena yang melakukan adalah 
badan/pejabat pemerintah. Hal ini sejalan dengan penilaian negatif atas konsep diskresi yang dikemukakan oleh Herbert Packer: "The basic trouble with discretion is simply that it is lawless, in the literal sense of that term."

Menurut B.V. Harris sebagaimana dikutip oleh Krishna, diskresi pada hakikatnya menampakkan satu kecenderungan berupa pengecualian dari keharusan bertindak sesuai aturan umum (general rule) dari peraturan perundang-undangan (pendekatan rule-based atau rule following). Pengecualian tersebut mengandung karakter yang berhubungan erat dengan kebebasan yang disertai dengan ruang lingkup luas secara fungsional berbanding lurus terhadap cakupan dari kekuasaan/kewenangan yang dimiliki oleh badan/pejabat pemerintah. Bahkan lebih jauh lagi ada pandangan yang beranggapan bahwa badan/pejabat pemerintah secara melekat (inheren) memiliki kebebasan bertindak residual tanpa adanya otorisasi undang-undang sekalipun. Pemikiran ini timbul dari asumsi bahwa pemerintah boleh melakukan tindakan apapun sepanjang tidak melanggar hukum atau hak-hak individual. Pandangan ini mengakui bahwa kedudukan pemerintah sama dengan individu yang diandaikan sama-sama memiliki kebebasan dan boleh melakukan apapun sepanjang tidak dilarang oleh hukum. Itu artinya, undang-undang atau putusan pengadilan dapat membatasi kebebasan tersebut. Sepanjang hal itu tidak dilakukan maka dianggap pemerintah memiliki kebebasan bertindak. Pengertian ini dikonsepsikan sebagai "the third source authority for government action" 8

Pengertian diskresi nampak lebih konkret menurut pendapat Charles $\mathrm{H}$. Koch, Jr dalam Krishna, yang menjelaskan lima makna konsep diskresi (administrative discretion), yaitu: individualizing discretion, executing discretion, policy making discretion, unbridled discretion, dan numinous discretion). Menurutnya berdasarkan kriteria tersebut, memungkinkan pengadilan dapat tidaknya menguji tindakan diskresi tersebut. Lebih lanjut Koch, Jr menjelaskan bahwa semangat yang dikandung oleh konsep diskresi 
adalah untuk memberikan perlindungan bagi pejabat yang menjalankannya berupa ruang kebebasan atau kemungkinan terjadinya kesalahan ketika melakukan tindakan tersebut. ${ }^{9}$

Menurut Sjachran Basah sebagaimana dikutip oleh Ridwan HR, freies ermessen (diskresi) yang diberikan kepada pemerintah atau administrasi negara merupakan konsekuensi logis dari konsepsi welfare state, akan tetapi dalam kerangka negara hukum freies ermessen tidak dapat digunakan tanpa batas. Atas dasar itu Sjachran Basah mengemukakan unsur-unsur freies ermessen dalam suatu negara hukum yaitu: ${ }^{10}$

a. Ditujukan untuk menjalankan tugas-tugas servis publik;

b. Merupakan sikap tindak yang aktif dari administrasi negara;

c. Sikap tindak itu dimungkinkan oleh hukum;

d. Sikap tindak itu diambil atas inisiatif sendiri;

e. Sikap tindak itu dimaksudkan untuk menyelesaikan persoalan-persoalan penting yang timbul secara tiba-tiba;

f. Sikap tindak itu dapat dipertanggungjawabkan baik secara moral kepada Tuhan yang Maha Esa maupun secara hukum.

Penggunaan asas diskresi merupakan sarana bagi aparat pemerintah untuk melakukan terobosan-terobosan serta pemecahan-pemecahan masalah yang membutuhkan penyelesaian yang cepat dan belum ada aturan yang mengatur tentang hal tersebut. Konsekuensi yuridis dengan adanya penggunaan diskresi yang tidak didasarkan pada tujuan, peraturan perundang-undangan, dan asas-asas umum pemerintahan yang baik berakibat diskresi tersebut akan mendorong terjadinya tindakan sewenang-wenang dan penyalahgunaan wewenang. Tindakan sewenang-wenang dapat terjadi karena pemerintah tidak cukup memiliki rasionalitas sebagai parameternya. Oleh karena itu, setiap diskresi pemerintah harus didasarkan pada asas legalitas, asas demokrasi, asas

\footnotetext{
Ibid, halaman 25

Ridwan HR, Op cit, halaman 170-171
} 
tujuan, dan asas-asas umum pemerintahan yang baik sebagai metanorm yang melandasi tindakan pemerintahan. ${ }^{11}$

Menurut Pasal 1 angka 9 Undang-Undang Nomor 30 Tahun 2014 tentang Administrasi Pemerintahan, “diskresi adalah keputusan dan/atau tindakan yang ditetapkan dan/atau dilakukan oleh Pejabat Pemerintahan untuk mengatasi persoalan konkrit yang dihadapi dalam penyelenggaraan pemerintahan dalam hal peraturan perundang-undangan yang memberikan pilihan, tidak mengatur, tidak lengkap atau tidak jelas, dan/atau adanya stagnasi pemerintahan."

Undang-Undang Nomor 30 Tahun 2014 tentang Administrasi Pemerintahan Pasal 22 ayat (1) menyatakan bahwa: "Diskresi hanya dapat dilakukan oleh Pejabat Pemerintahan yang berwenang."

Selanjutnya ayat (2) menyatakan bahwa setiap penggunaan diskresi Pejabat Pemerintahan bertujuan untuk:

a. melancarkan penyelenggaraan pemerintahan;

b. mengisi kekosongan hukum;

c. memberikan kepastian hukum; dan

d. mengatasi stagnasi pemerintahan dalam keadaan tertentu guna kemanfaatan dan kepentingan umum.

Pasal 23 Undang-Undang Nomor 30 Tahun 2014 mengatur tentang lingkup diskresi pejabat pemerintahan yang meliputi:

a. pengambilan Keputusan dan/atau Tindakan berdasarkan ketentuan peraturan perundang-undangan yang memberikan suatu pilihan Keputusan dan/atau Tindakan;

b. pengambilan Keputusan dan/atau Tindakan karena peraturan perundangundangan tidak mengatur;

c. pengambilan Keputusan dan/atau Tindakan karena peraturan perundangundangan tidak lengkap atau tidak jelas; dan

11 Didik Hery Santosa, Penggunaan Asas Diskresi dalam Pengambilan Keputusan, e-Jurnal http://www.bppk.kemenkeu.go.id/publikasi/artikel/418-artikel-soft-competency/23181-penggunaanasas-diskresi-dalam-pengambilan-keputusan 
d. pengambilan Keputusan dan/atau Tindakan karena adanya stagnasi pemerintahan guna kepentingan yang lebih luas.

Menurut Pasal 24 Undang-Undang Nomor 30 Tahun 2014, Pejabat Pemerintahan yang menggunakan diskresi harus memenuhi syarat:

a. sesuai dengan tujuan diskresi sebagaimana dimaksud dalam Pasal 22 ayat (2);

b. tidak bertentangan dengan ketentuan peraturan perundang-undangan;

c. sesuai dengan AUPB;

d. berdasarkan alasan-alasan yang objektif;

e. tidak menimbulkan konflik kepentingan; dan

f. dilakukan dengan iktikad baik.

\section{B. Pembahasan}

Dalam kasus Rumah Sakit Sumber Waras Jakarta, pembelian sebagian lahan milik Yayasan Kesehatan Sumber Waras oleh Pemerintah Provinsi DKI Jakarta masih menjadi polemik. Kompas.com Selasa, 19 April 2016 memberitakan bahwa hasil audit Badan Pemeriksa Keuangan (BPK) menyebut adanya indikasi kerugian negara sebesar Rp 191 miliar, sedangkan Gubernur DKI Jakarta menyatakan bahwa pembelian lahan itu telah sesuai prosedur dan menguntungkan Pemprov DKI.

Sebelumnya Badan Pemeriksa Keuangan (BPK) menilai proses pembelian sebagian lahan RS Sumber Waras oleh Pemprov DKI tidak sesuai dengan prosedur. Pemprov DKI Jakarta membeli lahan milik Yayasan Kesehatan Sumber Waras (YKSW) senilai Rp 800 miliar pada Anggaran Pendapatan dan Belanja Daerah (APBD) Perubahan tahun 2014. Pemprov DKI disebut membeli harga lebih mahal dari seharusnya sehingga mengakibatkan kerugian negara sebesar Rp 191 miliar.

KPK telah menyatakan tidak menemukan adanya tindak pidana dalam kasus pembelian lahan milik Rumah Sakit Sumber Waras, Jakarta Barat oleh Pemerintah Provinsi DKI Jakarta. Menurut Fokusnusa.com tanggal 27 Mei 2016 yang mengutip Kompasiana.com, pada kasus RS Sumber Waras memang hingga kini, KPK belum menemukan adanya kerugian negara dan niat jahat Ahok pada pembelian lahan RS Sumber Waras oleh Pemerintah Provinsi DKI tahun 2014 lalu sebagaimana yang 
ditudingkan BPK DKI. Soal letak tanah RS Sumber Waras yang menentukan di Jl. Kyai Tapa adalah BPN DKI, soal NJOP yang menentukan besarannya adalah Dirjen Pajak. KPK mengikuti pendapat BPN DKI dan Dirjen Pajak Kementerian Keuangan. Menurut KPK, Ahok sudah benar membayar lahan RS Sumber Waras tersebut dengan NJOP Kyai Tapa dengan nilai sebesar Rp 20,7 juta/meter. Sehingga Ahok dinilai KPK tidak merugikan keuangan negara. Karena negara tidak dirugikan, maka KPK juga menilai Ahok tidak memiliki niat jahat untuk memenuhi koceknya, mencuri dana dari pembelian lahan RS Sumber Waras oleh Pemerintah Provinsi DKI tahun 2014. "Maka tidak sederhana mengusut kasus ini, ada kerugian negara, niat buruk, perhitungan yang dilakukan. Ini yang kita harus lebih dibuka, ini kasus ujungnya pidana atau tidak.” Ujar Wakil Ketua KPK Saut Situmorang. Sampai sekarang, menurut Saut Situmorang, KPK belum juga menemukan adanya kerugian negara dan niat jahat Ahok pada pembelian lahan RS Sumber Waras dimaksud. Akibatnya sampai sekarang KPK tidak beralasan hukum untuk menetapkan Ahok sebagai tersangka kasus RS Sumber Waras.

Terhadap pembelian lahan RS Sumber Waras oleh Pemerintah Provinsi DKI tersebut, BPK memberikan opini dan rekomendasi yang secara umum disampaikan oleh BPK terhadap Laporan Keuangan Pemerintah Provinsi DKI Tahun 2014 pada Senin 6 Juli 2015. BPK Perwakilan Provinsi DKI Jakarta memberikan Opini Wajar dengan Pengecualian (WDP) atas Laporan Keuangan Pemerintah Provinsi DKI Jakarta Tahun Anggaran 2014. Opini tersebut diberikan setelah BPK melakukan pemeriksaan yang terdiri dari Laporan Realisasi Anggaran, Neraca, Laporan Arus Kas dan Catatan atas Laporan Keuangan. Dari temuan pemeriksaan tersebut, terdapat permasalahan signifikan yang perlu mendapat perhatian yaitu antara lain pengadaan tanah RS Sumber Waras tidak melalui proses yang memadai sehingga berindikasi merugikan daerah senilai Rp 191,33 milyar.

BPK juga merekomendasikan untuk melakukan upaya pembatalan pembelian tanah RS Sumber Waras seluas $36.410 \mathrm{~m} 2$ dengan pihak YKSW. Jika 
pembatalan tidak dapat dilaksanakan, supaya meminta pertanggungjawaban kepada pihak YKSW sesuai ketentuan yang berlaku. ${ }^{12}$

Audit BPK tersebut di atas oleh sejumlah pakar dinilai keliru. Dalam catatan yang terangkum pada buku berjudul Jalan Lurus Menuju Sumber Waras, tim penulis yang dikepalai mantan auditor BPKP, Leonardus Joko Eko Nugroho, menilai, hasil audit BPK keliru. Kekeliruan audit BPK yang pertama ada pada penetapan alamat pembelian lahan. BPK merujuk pada NJOP Jalan Tomang Utara, yakni Rp 7 juta per meter persegi. Sementara itu Pemprov DKI Jakarta merujuk ke Jalan Kyai Tapa dengan NJOP pada tahun pembelian atau tahun 2014 sebesar Rp 20,7 juta per meter persegi. "Lokasi RS Sumber Waras berada di Jalan Kyai Tapa sesuai dengan dokumen yang dikeluarkan BPN dan Dirjen Pajak. Argumentasi BPK bahwa lokasi Sumber Waras di Jalan Tomang Utara adalah salah alamat dan terlalu mengadaada."

Pakar Hukum Tata Negara Refly Harun menggarisbawahi mens area dalam beberapa kasus yang menjerat Ahok. Refly menilai, niat jahat ini menjadi kunci untuk membedakan pejabat yang buruk dengan yang baik. Pasalnya kesalahan saja tidak bisa membuat pejabat dipidanakan. Kerugian, misalnya, tidak dinilai sebagai kejahatan atau kesalahan berat dalam kebijakan pejabat. Terkait kasus Sumber Waras, Pemprov tentu tidak bisa membatalkan pengadaan lahan yang sudah dibayarkan itu. Yayasan Sumber Waras belum tentu mau membeli lagi lahan yang dijualnya dengan harga yang sama.

Dalam berbagai kesempatan, Ahok sering mengatakan bahwa ia tidak senang dengan proses birokrasi yang berbelit-belit dalam pengadaan barang dan jasa. Iapun selalu berpegangan pada celah hukum yang dapat memangkas prosedur yang lama. Dalam kasus Sumber Waras, misalnya, temuan BPK terkait prosedur pengadaan, seperti penunjukan lokasi,studi kelayakan, kajian teknis, dan penetapan lokasi, dapat dimentahkan melalui Pasal 121 Peraturan Presiden Nomor 40 Tahun 2014, yang berbunyi: "Demi efisiensi dan efektivitas pengadaan tanah di bawah 5 (lima) hektar dapat dilakukan pembelian langsung antara instansi yang memerlukan tanah dengan

12 jakarta.bpk.go.id/?p=6369, 
pemegang hak atas tanah atau dengan cara lain yang disepakati kedua belah pihak.” Lahan Sumber Waras seluas 3,6 hektar seharusnya dapat dibeli tanpa pusing-pusing meributkan appraisal, penawaran pihak lain, dan penentuan NJOP. ${ }^{13}$

Dalam kasus reklamasi teluk Jakarta, maka soal Diskresi Reklamasi, Dian Simatupang menyatakan bahwa perbuatan diskresi Ahok kepada para perusahaan pengembang Reklamasi Pantai Utara, terkait kontribusi tambahan pengembang reklamasi pantai utara Kota Jakarta sudah tepat dan benar.” Ketentuan itu sudah cocok untuk menangani stagnasi kebijakan lantaran belum ada regulasi yang mengaturnya "Pada kasus Reklamsi Pantai Utara Jakarta, negara tidak dirugikan sebagaimana yang dimaksud Pasal 3 Undang-Undang Nomor 31 Tahun 1999 jo Undang-Undang Nomor 20 Tahun 2001 tentang Tindak Pidana Korupsi, malah negara diuntungkan dengan ada penambahan aset Pemprov DKI dari pemberian PT. Agung Podomoro Land, berupa Rusun di Daan mogot, Jalan Inspeksi di Kalijodo dan Furnitur untuk Rumah Susun. ${ }^{14}$

Menurut Ahok sebagaimana dimuat dalam news.detik.com, Kamis 06 Oktober 2016, diskresi yang dikeluarkannya telah sesuai dengan Undang-Undang Nomor 30 Tahun 2014. Dalam pernyataannya, Ahok menggarisbawahi materi dalam Undang-Undang Nomor 30 Tahun 2014 tentang Administrasi Pemerintahan. Diskresi yang ia keluarkan bukanlah untuk menguntungkan dirinya, melainkan untuk Pemprov DKI Jakarta, ujar Ahok di Balai Kota, Jalan Medan Merdeka Selatan, Jakarta Pusat, Kamis (6/10/2016).

Diskresi yang dikeluarkan terkait tambahan kontribusi 15 persen untuk pengembang reklamasi, dijelaskan oleh Ahok telah ada presedennya. Selain itu, Ahok juga menambahkan bahwa kontribusi tambahan sudah dilakukan sejak zaman Presiden Soeharto. Hal itu berdasar pada surat dari Menteri Negara Perencanaan Pembangunan Nasional/ Ketua Bappenas Ginandjar Kartasasmita pada 10 Maret 1997. Salah satu isi surat terulis,"Pola kompensasi dan pola pengembangan di kawasan barat pantura Jakarta dilaksanakan mengikuti pola Kapuk Naga yang lebih

13 http://megapolitan.kompas.com/read/2016/06/03/09190231/mencari.mens.rea.ahok.di.kasus. lahan. rs.sumber.waras

14 Fokusnusa.com tanggal 27 Mei 2016 
luas, yang antara lain berupa teknik reklamasi menggunakan sistem polder dan kompensasi tanah matang untuk pemerintah daerah sebesar lima persen dari luas kotor dari daerah luas kotor daerah reklamasi." "Kenapa ada kontribusi tambahan, karena mengacu ke Perda Nomor 8 Tahun 1995 di situ disebutkan orang kalau reklamasi pulau harus membereskan daratan. Apa yang dimaksud membereskan daratan adalah rumah susun, jalan inspeksi, rumah pompa, danau untuk mengatasi banjir dan mindahin orang. Lalu sekarang ketika saya meminta pengembang melakukan kontribusi tambahan itu dengan mengacu tahun 95-97 apakah saya ciptakan? Bukan," tegasnya.

Sebelumnya, Wakil Ketua KPK Laode M Syarif mengatakan akan menindaklanjuti fakta persidangan terkait diskresi tambahan kontribusi pengembang yang dikeluarkan oleh Ahok. "Semua yang berhubungan dengan fakta-fakta persidangan kan pasti akan ditindaklanjuti oleh penyidik-penyidik kita. Tapi kalau misalnya sudah ada peraturannya tapi enggak diikuti, nah itu bukan diskresi yang baik. Kalau misalnya diskresi tapi hanya untuk memperkaya diri sendiri itu juga enggak benar. (Soal diskresi tambahan kontribusi yang dilakukan Ahok) itu yang akan KPK teliti," ujar Laode. ${ }^{15}$

Berdasarkan kedua kasus tersebut di atas, yaitu kasus Rumah Sakit Sumber Waras Jakarta dan kasus Reklamasi Teluk Jakarta, maka pertanggungjawaban pejabat pemerintahan dalam hal ini Basuki Tjahaya Purnama (Ahok) selaku Gubernur DKI Jakarta pada waktu itu telah menjalankan diskresi berdasarkan ketentuan peraturan perundang-undangan. Diskresi pejabat pemerintahan diatur dalam Undang-Undang Nomor 30 Tahun 2014 tentang Administrasi Pemerintahan.

Menurut Pasal 6 ayat (2) huruf e Undang-Undang Nomor 30 Tahun 2014, diskresi merupakan salah satu hak yang dimiliki oleh Pejabat Pemerintahan untuk menggunakan kewenangan dalam mengambil Keputusan dan/atau Tindakan. Dengan demikian Pejabat Pemerintahan berhak menggunakan diskresi sesuai dengan tujuannya. Di sisi lain Pejabat Pemerintahan berkewajiban untuk menyelenggarakan administrasi pemerintahan yang sesuai dengan ketentuan 
peraturan perundang-undangan, kebijakan pemerintahan, dan AUPB, sebagaimana diatur dalam Pasal 7 ayat (1) Undang-Undang Nomor 30 Tahun 2014 tentang Administrasi Pemerintahan.

Ketentuan penggunaan diskresi dapat dilihat dalam Pasal 9 ayat (4) UndangUndang Nomor 30 Tahun 2014 "Ketiadaan atau ketidakjelasan peraturan perundang-undangan sebagaimana dimaksud pada ayat (2) huruf b, tidak menghalangi Badan dan/atau Pejabat Pemerintahan yang berwenang untuk menetapkan dan/atau melakukan Keputusan dan/atau Tindakan sepanjang memberikan kemanfaatan umum dan sesuai dengan AUPB.” Dalam Penjelasannya dinyatakan bahwa pertimbangan kemanfaatan umum atas satu Keputusan dan/atau Tindakan tidak boleh melanggar norma agama, sosial, dan kesusilaan. Kemanfaatan umum harus memberikan dampak pada peningkatan kesejahteraan dan kepentingan warga masyarakat.

Asas-asas Umum Pemerintahan yang Baik (AUPB) yang dimaksud adalah AUPB sebagaimana diatur dalam Pasal 10 ayat (1) Undang-Undang Nomor 30 Tahun 2014, yaitu:

a. Kepastian hukum;

b. Kemanfaatan;

c. Ketidakberpihakan;

d. Kecermatan;

e. Tidak menyalahgunakan kewenangan;

f. Keterbukaan;

g. Kepentingan umum; dan

h. Pelayanan yang baik.

Prosedur penggunaan diskresi menurut Pasal 26 ayat (1) dan ayat (2) Undang-Undang Nomor 30 Tahun 2014 adalah sebagai berikut:

(1) Pejabat yang menggunakan Diskresi sebagaimana dimaksud dalam Pasal 25 ayat (1) dan ayat (2) wajib menguraikan maksud, tujuan, substansi, serta dampak administrasi dan keuangan. 
(2) Pejabat yang menggunakan Diskresi sebagaimana dimaksud pada ayat (1) wajib menyampaikan permohonan persetujuan secara tertulis kepada Atasan Pejabat.

Pada dasarnya penggunaan diskresi oleh Pejabat Pemerintahan tidak dapat dipidanakan, selama Pejabat Pemerintahan tersebut menggunakan diskresi tidak secara melawan hukum yang dapat merugikan keuangan negara. Hal tersebut dimaksudkan agar Pejabat Pemerintahan tidak takut menggunakan diskresi dalam mengambil Keputusan dan/atau Tindakan.

Menindaklanjuti ketentuan Pasal 21 Undang-undang Nomor 30 Tahun 2014 tentang Administrasi Pemerintahan, maka Mahkamah Agung mengeluarkan Peraturan Mahkamah Agung Nomor 4 Tahun 2015 tentang Penilaian Unsur Penyalahgunaan Wewenang. Sebagai pihak pemohon adalah Badan/Pejabat Pemerintahan.

Pengadilan Tata Usaha Negara berwenang menilai ada tidaknya unsur penyalahgunaan wewenang yang dilakukan oleh Pejabat Pemerintahan. Hal tersebut diatur dalam Pasal 21 sebagaimana berikut:

\section{Pasal 21}

(1) Pengadilan berwenang menerima, memeriksa, dan memutuskan ada atau tidak ada unsur penyalahgunaan Wewenang yang dilakukan oleh Pejabat Pemerintahan.

(2) Badan dan/atau Pejabat Pemerintahan dapat mengajukan permohonan kepada Pengadilan untuk menilai ada atau tidak ada unsur penyalahgunaan Wewenang dalam Keputusan dan/atau Tindakan.

(3) Pengadilan wajib memutus permohonan sebagaimana dimaksud pada ayat (2) paling lama 21 (dua puluh satu) hari kerja sejak permohonan diajukan.

(4) Terhadap putusan Pengadilan sebagaimana dimaksud pada ayat (3) dapat diajukan banding ke Pengadilan Tinggi Tata Usaha Negara.

(5) Pengadilan Tinggi Tata Usaha Negara wajib memutus permohonan banding sebagaimana dimaksud pada ayat (4) paling lama 21 (dua puluh satu) hari kerja sejak permohonan banding diajukan. 
(6) Putusan Pengadilan Tinggi Tata Usaha Negara sebagaimana dimaksud pada ayat (5) bersifat final dan mengikat.

Menurut Krishna Djaya Darumurti telah terjadi kekeliruan dalam mengartikan penyalahgunaan wewenang sebagaimana diatur dalam Undang-Undang Nomor 30 Tahun 2014. Penyalahgunaan wewenang (detournement de pouvoir) berbeda dengan bertindak sewenang-wenang (willekeur). Ada tidaknya unsur penyalahgunaan wewenang diuji dengan Asas-asas Umum Pemerintahan yang Baik yakni asas yang menentukan bahwa wewenang itu diberikan kepada organ pemerintahan dengan tujuan tertentu. Jika menyimpang dari tujuan diberikannya wewenang ini dianggap sebagai penyalahgunaan wewenang. Unsur sewenangwenang diuji dengan asas rasionalitas atau kepantasan (redelijk). Suatu kebijakan dikategorikan mengandung unsur willekeur jika kebijakan itu nyata-nyata tidak masuk akal atau tidak beralasan (konnelijk onredelijk). ${ }^{16}$

Dalam kasus Rumah Sakit Sumber Waras Jakarta, Sarmauli Mutiara Marpaung menyatakan bahwa terhadap Rumah Sakit Sumber Waras Jakarta BPK melakukan audit investigatif terhadap Laporan Hasil Pemeriksaan atas Laporan Keuangan Pemerintah Provinsi DKI Jakarta Tahun 2014, khususnya yang menyangkut Rumah Sakit Sumber Waras. Oleh karena itu maka audit investigatif BPK tersebut tidak dapat dipublikasikan kepada masyarakat sebagaimana tercantum dalam Keputusan Sekretaris Jenderal Badan Pemeriksa Keuangan Republik Indonesia Nomor 551/K/X-XIII.2/11/2016 tentang Daftar Informasi Publik yang Dikecualikan di Lingkungan Badan Pemeriksa Keuangan. ${ }^{17}$

Pertanggungjawaban Ahok sebagai Pejabat Pemerintahan menggunakan diskresi dalam kasus Rumah Sakit Sumber Waras dan reklamasi Teluk Jakarta tidak dapat dikategorikan menimbulkan akibat hukum yang berpotensi membebani keuangan negara sebagaimana diatur dalam Pasal 25 ayat (2) Undang-Undang Nomor 30 Tahun 2014 tentang Administrasi Pemerintahan. Diskresi tersebut tidak

16 Krishna Djaya Darumurti, Op Cit, 133

17 Sarmauli Mutiara Marpaung, Wawancara, Kepala Subdirektorat Pengembangan Hukum BPK, Jakarta, 11 Oktober 2017 
menimbulkan kerugian keuangan negara walaupun dalam kasus Rumah Sakit Sumber Waras masih terdapat polemik di dalam penyelesaiannya. Sedangkan dalam kasus reklamasi Teluk Jakarta permasalahan utama bukan terhadap kebijakan diskresi yang dilakukan Ahok namun lebih kepada permasalahan lingkungan hidup dan kehidupan nelayan. Terhadap kedua kasus tersebut Ahok telah menjalankan diskresi sebagaimana diatur dalam Pasal 1 angka 9 Undang-Undang Nomor 30 Tahun 2014 tentang Administrasi Pemerintahan.

Dalam negara hukum, pertanggungjawaban pejabat pemerintahan merupakan suatu keharusan. Pengecualian terhadap asas legalitas dengan menggunakan asas diskresi tetap harus dapat dipertanggungjawabkan, karena tanpa pertanggungjawaban maka tindakan diskresi Pemerintah dapat berpotensi disalahgunakan.

\section{Simpulan}

Berdasarkan penelitian yang telah dilakukan, maka dapat disimpulkan halhal sebagai berikut:

1. Freies Ermessen atau diskresi dimiliki oleh setiap pemegang jabatan atau pejabat pemerintahan untuk mengambil kebijakan strategis berupa keputusan dan/atau tindakan dalam mengatasi persoalan konkret yang mendesak yang membutuhkan penanganan segera. Diskresi merupakan kebijakan Pejabat Pemerintahan. Regulasi tentang diskresi tersebut terdapat dalam UndangUndang Nomor 30 Tahun 2014 tentang Administrasi Pemerintahan.

2. Dalam kasus Rumah Sakit Sumber Waras dan Reklamasi Teluk Jakarta, diskresi Ahok selaku Pejabat Pemerintahan (Gubernur DKI Jakarta) telah dilakukan dan memenuhi ketentuan Undang-Undang Nomor 30 Tahun 2014 tentang Administrasi Pemerintahan. Tidak ditemukan adanya penggunaan diskresi yang menimbulkan akibat hukum berpotensi membebani keuangan negara. Dalam kasus Rumah Sakit Sumber Waras masih terdapat polemik soal penghitungan NJOP antara BPK dengan KPK berkaitan dengan letak tanah. Letak tanah Rumah Sakit Sumber Waras di Jalan Kyai Tapa ditentukan oleh BPN DKI, sedangkan besaran NJOP yang menentukan adalah Dirjen Pajak. Pemprov DKI mengikuti pendapat BPN DKI dan Dirjen Pajak Kementerian Keuangan, 
sedangkan BPK DKI menilai NJOP Rumah Sakit Sumber Waras di Jalan Tomang Utara. KPK mengikuti pendapat BPN DKI dan Dirjen Pajak Kementerian Keuangan, sehingga Ahok dinilai KPK tidak melakukan perbuatan melawan hukum yang merugikan keuangan negara, walaupun sampai saat ini KPK masih melakukan penyelidikan berdasarkan hasil audit BPK. Dalam kasus Reklamasi Teluk Jakarta, Ahok telah tepat dalam menggunakan diskresi untuk menangani terjadinya stagnasi pemerintahan berkaitan dengan kebijakan yang harus diambil Ahok selaku Pejabat Pemerintahan. Masalah utamanya bukan pada diskresi, namun pada pengelolaan lingkungan hidup dan keberlanjutan kehidupan nelayan pesisir pantai utara Jakarta.

\section{Daftar Pustaka}

Darumurti, Krishna Djaya 2016, Diskresi Kajian Teori Hukum, (Yogyakarta: Genta Publishing);

Denim, Sudarwan, 2002, Menjadi Peneliti Kualitatif, (Bandung: Pustaka Setia);

Hadjon, Philipus M. dkk 2011, Hukum Administrasi dan Tindak Pidana Korupsi, (Yogyakarta: Gadjah Mada University Press);

HR, Ridwan, 2013, Hukum Administrasi Negara Edisi Revisi, (Jakarta: Raja Grafindo Persada);

Idrus, Muhammad, 2007, Metode Penelitian Ilmu-Ilmu Sosial, (Yogyakarta: UII Press);

Makawimbang, Hernold Ferry, 2014, Kerugian Keuangan Negara, (Yogyakarta: Thafa Media);

Marbun, SF dan Moh. Mahfud MD, 1987, Pokok-pokok Hukum Administrasi Negara,( Yogyakarta: Liberty);

Soemitro, Ronny Hanitijo, 1994, Metodologi Penelitian Hukum dan Yurimetri, (Jakarta: Ghalia Indonesia);

Soerjono Soekanto, 1981, Pengantar Penelitian Hukum, (Jakarta: UI-Press);

Tjandra, W Riawan, 2008, Hukum Administrasi Negara, (Yogyakarta: Penerbit Universitas Atmajaya);

Waluyo, Bambang, 1991, Penelitian Hukum dalam Praktek, (Jakarta: Sinar Grafika).

Kartika Widya Utama, 2015, Quo Vadis Undang-undang No.5 Tahun 1986 tentang Peradilan Tata Usaha Negara Jis. Undang-undang No. 51 Tahun 2009 dan Kompetensi Peradilan Tata Usaha Negara dalam UU no. 30 Tahun 2014 tentang Administrasi Pemerintahan Negara, Jurnal Masalah-masalah Hukum, jilid 44 No. 3, Juli 2015 
Santosa, Didik Hery, 2016, Penggunaan Asas Diskresi dalam Pengambilan Keputusan, e-Jurnal http://www.bppk.kemenkeu.go.id/publikasi/artikel/ 418-artikel-softcompetency/23181-penggunaan-asas-diskresi-dalam-pengambilan-keputusan

Sarmauli Mutiara Marpaung, Wawancara, Kepala Subdirektorat Pengembangan Hukum BPK, Jakarta, 11 Oktober 2017 